\title{
KONSEP DAN IMPLEMENTASI KEPEMIMPINAN ISLAMI DI UIN MALIKI MALANG
}

\author{
Iffi Nur Diana \\ Pasca Sarjana Unair Surabaya, Telp. 081615178305 \\ email: ilfi_nur@yahoo.com
}

\begin{abstract}
Moslem intellectuals, inter alia : al Farabi, al Mawardi, al Ghazali, Ibnu Taimiyah, Inbu Khaldun, and Jamaludin al Afghani have factually addressed concepts of Islamic leadership since the classical era. Unfortunately, only a few Moslem researchers further study them and they are not yet further developed optimally. Accordingly, it is deemed necessary to further study about Islamic leadership by identifying the parameters advocated by Moslem leaders. The purpose of this study is to explore of Islamic leadership at Maliki Islamic State University (UIN) Malang. This research used 144 employees as samples. To test Islamic leadership at this unversity, factor analysis is used. The results of factor analysis showed that of the 30 proposed questions, 5 of them were excluded, namely :sincerity (not expecting material rewards), tenacity, friendliness, firmness to give sanctions to indiscipline subordinates and deliberation (openness to accept inputs from subordinates), and the extracted factors were 8 Accumulatively, Islamic leadership was justified by $68.8 \%$. p. It was conclusive that the research contributed to Islamic leadership parameters adopted from the thoughts of classical through modern Moslem intelectuals.

Para pemikir Muslim seperti: al Farabi, al Mawardi, al Ghazali, Ibnu Taimiyah, Ibn Khaldun, and Jamaludin al Afghani telah secara gamblang mengulas konsep kepemimpinan dalam Islam sejak zaman klasik. Akan tetapi, hanya sedikit dari pemikir Islam yang melakukan studi mendalam tentang kepemimpinan. Oleh karena itu, penelitian lanjut di bidang kepemimpinan dalam Islam dengan mengidentifikasi parameter yang telah ditetapkan oleh para pemimpin Islam sangat diperlukan. Tujuan dari studi ini untuk merambah kepemimpinan Islam
\end{abstract}


di Universitas Islam Negeri (UIN) Maliki Malang. Penelitian ini menggunakan 144 pegawai sebagai contoh. Faktor analisis digunakan dalam penelitian ini untuk mengukur kepemimpinan Islam. Dalam proses penelitian, lima dari tiga puluh pertanyaan yang diajukan telah dikesampingkan, diantaranya adalah keihklasan (mengharakan imbalan), ketegasan, keramahan, keras dalam memberikan sangsi untuk mendisiplinkan bawahan dan demokratis (keterbukaan menerima masukan dari bawahan). Hasil dari factor-faktor yang dipakai dalam penelitian ini adalah delapan. Secara akumulatif, kepemimpinan Islam mencapai 68.8\%. Dapat disimpulkan bahwa penelitian ini berkontribusi pada parameter kepemimpinan Islam sebagaimana diadopsi dari pemikiran klasik melalui pemikir modern

Key words: leadership, Islamic leadership, UIN Maliki

\section{Pendahuluan}

Kajian mengenai kepemimpinan memang termasuk kajian yang multidimensi, berbagai teori telah dihasilkan dari kajian ini. Teori yang paling tua adalah The Trait Theory atau yang biasa disebut teori Pembawaan/karakter (Yukl, 2001:13; Kreitner and Kinicki, 2005:303). Selanjutnya, berkembang teori perilaku, yang lebih dikenal dengan Behaviorist Theories (Yukl,2001:14). Pada masa berikutnya teori tersebut dianggap tidak lagi relevan dengan situasi dan kondisi zaman, maka berkembanglah model kepemimpinan situasional. Pendekatan ini menjadi trend pada tahun 1950-an. Selanjutnya pendekatan teori-teori kepemimpinan baru, yaitu teori Leader Member Exchange/LMX, karismatik, dan transaksional dan transformasional (Kreiter and Kinicki,2005:318; Yukl 2001:140).

Perkembangan tersebut sesungguhnya dalam proses mencari kepemimpinan yang efektif dan strategis dalam sebuah organisasi. Adapun teori yang paling modern dan banyak diadopsi oleh berbagai organisasi saat ini adalah teori kepemimpinan transformasional, namun kenyataannya, hal ini juga tidak banyak membantu dalam perubahan organisasi. Krisis terbesar saat ini adalah krisis keteladanan dari seorang pemimpin. Seperti halnya di Indonesia, masalah moral menempati posisi yang sangat memprihatinkan, dan sikap korup masih mewarnai pemerintahan, organisasi, perusahaan, bahkan lembaga pendidikan. Hal ini 
disebabkan absennya pemimpin yang visioner, kompeten, memiliki spiritual dan integritas yang baik, sehingga tidak dapat dijadikan teladan (Antonio,2007:3). Disinilah pentingnya dikembangkan kepemimpinan yang berbasis nilai-nilai Islam yang telah diajarkan oleh Rasulullah SAW.

Lembaga pendidikan Islam di Indonesia sangat banyak $( \pm 50$ PTAIN dan 350 PTAIS), namun hanya sedikit yang berkualitas dan mampu bersaing dengan lembaga pendidikan umum lainnya (Suprayogo,2009:5). Itulah sebabnya dalam mengelola lembaga pendidikan baik Islam, diperlukan seorang pemimpin yang tidak hanya dapat memimpin secara profesional tetapi juga mampu mempengaruhi dan menumbuhkan misi (niat) suci dan mental yang kuat dari bawahannya. Kepemimpinan adalah kemampuan mempengaruhi orang lain sehingga mereka dengan penuh semangat berusaha mencapai tujuan yang telah ditetapkan (Robbins 2008:49). Kepemimpinan dalam Islam merupakan sebuah proses mempengaruhi orang lain dengan memberikan keteladanan. Tentu saja keteladanan ini dapat dilihat dari sikap dan perilaku seorang pemimpin (Sihab,2005:482).

Kepemimpinan Islami sebenarnya telah diidentifikasi oleh para ulama klasik hingga kini. Namun tidak banyak dari para peneliti muslim yang mengkajinya baik secara kualitatif maupun kuantitatif. Oleh sebab itu sangat penting untuk dilakukan studi tentang kepemimpinan Islami, dengan mengidentifikasi ukuran-ukurannya dari para ulama, karena mereka telah melakukan ijtihad dari al Quran dan Hadits Nabi. Dalam studi ini akan digali indikator kepemimpinan Islami dan implementasinya di UIN Maliki Malang.

\section{Pemikiran Para Ulama tentang Kepemimpinan Islami}

\section{Al Farabi}

Al Farabi lahir pada tahun 870M (257H) dan mempunyai sekitar 100 karya ilmiah besar dan kecil meliputi berbagai disiplin ilmu (Bakar,1997:37). Adapun kriteria seorang pemimpin menurut pendapat (al Farabi versi 2.11:122123) adalah Tamam AlA'dlo' (anggota tubuh yang sempurna), Jayyidul fahmi wattashawwur (baik cara berfikir dan pemahamannya/visioner), Jayyidul Hifdzi (baik daya hafalnya terhadap perkara-perkara yang dipahami, dilihat, didengar dan dirasakannya), Dzaka' wal fathonah (cerdas dan cepat tanggap), Husnul Ibaroh (baik cara penyampaiannya dalam mengungkapkan segala sesuatu yang ada dalam benaknya/kemampuan berdiplomasi), Hubbul Ilmi (cinta kepada ilmu) dan gemar menggali berbagai faidah, Mubghidun Liladdzatiljismi/Iffah 
(terjaga dari godaan \& berbagai kelezatan duniawi), Muhibbun Lissidqi (cinta sifat jujur), Kabirunnafsi wa muhibbul karomah (mempunyai jiwa yang lapang dan kuat dalam menghadapi segala kesulitan), mempunyai jiwa yang mulia dan tidak mengutamakan harta benda sebagai tolak ukur utama, Muhibban lil adli wa mubghidon liddzulmi (cinta keadilan \& benci kedzaliman), Mempunyai prinsip yang kokoh dan Pemberani.

\section{Al Mawardi}

Al Mawardi Lahir di Basrah (Baghdad/Irak) pada 386 H/975 M. Ia termasuk penulis yang produktif, salah satu bukunya yang paling terkenal dalam bidang politik adalah Al Ahkamu As Sulthaniyah. Kepemimpinan menurut al Mawardi mempunyai dua tugas. Pertama; Likhilafati an-Nubuwwah fi Harosati ad din, yakni sebagai pengganti misi kenabian untuk menjaga agama. Dan kedua: Wa ssiyasyah ad dunnya, untuk memimpin atau mengatur urusan dunia.

Ia mengemukakan tujuh kriteria yang harus diperhitungkan untuk menjadi seorang pemimpin adalah adil dengan keseluruhan persyaratannya, berilmu pengetahuan sehingga mampu berijtihad dalam kasus-kasus yang dihadapi dan ketetapan-ketetapan hukum, memiliki kesempurnaan indra seperti pendengaran, penglihatan, dan pembicaraan agar dengannya ia bisa melaksanakan tugasnya sendiri, tidak memiliki cacat tubuh yang bisa menghalangi dinamika kerja dan tindakan segera, memiliki kemampuan menggagas (hal baru) yang dapat melahirkan strategi kepemimpinan rakyat dan pengaturan kemaslahatan (memberdayakan), berani dan tangguh sehingga mampu mempertahankan negara dan melawan musuh, nasab sang pemimpin hendaklah dari keturunan quraisy, dan mendapatkan kesepakatan (konsensus) (al Mawardi,1960: 6).

\section{Al Ghazali}

Ia dilahirkan di Thusia pada tahun $450 \mathrm{H}(1053 \mathrm{M})$, dan ia menulis 300 buah buku, bahkan seperti yang dikutip (Khudori, 2009: 22) bahwa karya-karyanya mencapai 457 buah meskipun umurnya tidak lebih 55 tahun. Dalam kitabnya At-tibr Al Masbuq fi nasihah al muluk, (alGhazali versi 2.11, vol.1:3) menyebutkan bahwa ada dua sifat yang harus dijadikan pedoman oleh seorang pemimpin sebagai wujud pertanggungjawabannya kelak diakhirat yaitu sifat Adil dan Inshof (memberikan sesuatu sesuai haknya). Lebih lanjut, dalam kitab yang sama (alGhazali, versi 2.11, vol.1: 3) dijelaskan bahwa diantara besarnya keutamaan seorang pemimpin adalah pemimpin yang 
mampu berbuat adil dalam sehari itu jauh lebih disenangi Allah daripada dia melakukan ibadah selama 70 tahun. Ia menceritakan bahwa banyak kerajaan bisa selalu eksis apabila dipenuhi dengan keadilan walaupun seluruh rakyat dan rajanya kafir, namun sebuah kerajaan mustahil bisa eksis apabila keadilan terabaikan walaupun seluruh penghuninya muslim. Terbukti dalam sebuah riwayat diceritakan bahwa kerajaan Majusi bisa selalu eksis dalam kurun waktu 4000 tahun lamanya hanya karena raja-raja mereka selalu menegakkan keadilan dan tidak pernah berbuat dzalim kepada rakyatnya. Rasulullah SAW bersabda: "Kerajaan akan eksis beserta dengan nuansa kekufuran, namun kerajaan tidak bisa eksis dalam nuansa penuh kedzaliman".

Setelah ditelusuri, kalimat tersebut di atas tidak ada dalam Kutubu al $H$ hadits al Tis'ah. Namun menurut beberapa versi diantaranya dalam kitab al I'jaz wal ijaz (Juz I:11) bahwa kalimat tersebut merupakan perkatan dari raja Habasy salah satu raja dari kerajaan Najasy. Kendatipun demikian, sebenarnya terdapat korelasi dengan kandungan salah satu ayat al Quran dalam penafsirannya menurut beberapa mufasir. yaitu dalam (QS: Hud 117). Dalam memahami ayat tersebut, Imam Ar Rozi memberikan penafsiran bahwa Allah SWT tidak akan pernah menghancurkan suatu daerah sebab penduduknya "dholim" (Musyrik), apabila mereka mampu berbuat baik antar satu dengan lainnya dalam menjalin interaksi mu'amalah (al Rozi,Juz 8:486). Akan tetapi Allah akan menurunkan adzab pada suatu kaum yang masyarakatnya tidak berbuat baik dalam muamalah dan penuh dengan perbuatan menyakitkan dan aniaya (al Ghazali,1983: 9).

Selanjutnya, al Ghazali (1983:148) memberi kriteria hampir sama dengan al Mawardi, yaitu mampu berbuat adil, melindungi rakyat dari kerusakan dan kriminalitas, tidak dzalim (tirani), memiliki integritas, penguasaan dalam bidang ilmu dan agama, agar dalam dalam menentukan kebijakan ia bisa berijtihad dengan benar, sehat panca inderanya (mata, pendengaran, lisan tidak terganggu yang dapat menghalangi ia menjalankan tugas), anggota badannya normal tidak cacat yang dapat mengganggu tugas, pemberani, memiliki keahlian (strategi), dan kemampuan intelektual untuk mengatur kemaslahatan rakyat.

\section{Ibnu Taimiyah}

Ahmad Ibnu Taimiyah lahir 22 Januari 1263 M di Damaskus. Karyanya dalam bidang politik adalah kitab al Syiyasah al Syariyah yang ditulis tahun 1311-1315 (Anthony,2001: 289). Menurutnya bahwa memilih pemimpin bukan atas dasar golongan dan hubungan kekerabatan pertemanan, kedaerahan, 
kesamaan ideologi, suap, permusuhan pribadi. Tetapi harus mengutamakan profesionalitas dan amanah (Mukti, 2010: 399).

Adapun kriteria memilih seorang pemimpin dengan merujuk al Quran (QS Al qashos: 26) adalah pilih yang paling baik/kuat dan amanah. Namun tidak banyak orang yang memiliki kriteria tersebut. Dalam mengangkat seorang pemimpin hendaknya lebih mempertimbangkan sosok yang lebih sesuai dengan keadaan dan kebutuhan wilayah tersebut. Maka tatkala dalam sebuah wilayah terdapat dua calon pemimpin yang mana salah seorang dari keduanya mempunyai sifat amanah yang baik namun lemah fisik sedangkan calon satunya mempunyai fisik yang kuat namun lemah amanahnya, maka yang harus didahulukan adalah calon pemimpin yang lebih sesuai dengan keadaan dan kebutuhan wilayah tersebut walaupun harus memilih orang yang lebih kuat fisiknya saja semisal wilayah tersebut sedang mengalami konflik atau peperangan, begitupun sebaliknya (Ibnu Taimiyah, versi 2.11).

\section{Ibnu Khaldun}

Ibn Khaldun lahir di Tunis, awal bulan Ramadhan tahun 732 H/1332 Masehi. Buku magnum opusnya adalah Al Muqaddimah. Menurutnya, definisi kepemimpinan atau Khilafah adalah mengajak keseluruhan rakyat menuju arah yang sesuai tuntutan syara demi mencapai maslahat dunia dan akhirat (Ibnu Khaldun, versi 2.11:97). Ia sepakat dengan ulama lainnya seperti al Mawardi, bahwa pemimpin adalah pengganti Nabi Muhammad dengan tugas mempertahankan agama dan menjalankan kepemimpinan dunia, yaitu menciptakan rasa aman, keadilan, kemaslahatan, menegakkan amar ma'ruf nahi munkar, mengayomi rakyat, mengatur dan menyelesaikan masalah masyarakat.

Ia menguraikan dimensi kepemimpinan (Ibnu Khaldun, versi 2.09: 98100) yaitu harus berilmu pengetahuan, adil, memiliki kesanggupan (capability), sehat jasmani dan rohani, keturunan Quraisy. Pemimpin harus berilmu sebab berperan sebagai figur yang menjalankan hukum-hukum Allah SWT, Jika tidak memiliki pengetahuan, maka bagaimana mungkin seorang pemimpin mampu memberikan keputusan atau kebijakan yang tepat. Pemimpin harus adil, karena adil merupakan suatu sifat dalam agama yang harus dimiliki dalam mengemban amanat apapun.

Mengenai keturunan Quraisy, ia berpendapat bahwa (Muqaddimah: 194) hal ini jangan diartikan bahwa kepemimpinan itu dimonopoli oleh suku Quraisy, atau faktor keturunan Quraisy didahulukan daripada faktor 
kemampuan. Ini hanya didasarkan pada kewibawaan dan solidaritas yang baik pada suku Quraisy pada saat itu, hingga ketika suku Quraisy telah dalam keadaan tidak berwibawa, atau ada suku lain yang mempunyai ashabiyyah yang baik dan kebibawaan yang baik, dan juga kepemimpinan dari suku Quraisy sudah tidak dapat lagi diharapkan, maka kepemimpinan dapat berpindah ke suku/kelompok lain yang mempunyai kewibawaan, solidaritas, dan kemampuan yang lebih. Persyaratan ini memang tampak sulit diterima oleh masyarakat modern. Karena itulah, sebagian ulama menolaknya. "Suku Quraisy" secara profesional dan dengan kacamata maqashid syariah (Fathiyah, 1984: 271). Keharusan pemimpin dari suku Quraisy itu hanya di saat suku terkuat adalah suku Quraisy. Tapi jika suku terkuat bukan Quraisy lagi maka kepemimpinan dipegang oleh suku terkuat lainnya.

\section{Jamaluddin AlAfghani}

Jamaluddin al Afghani lahir pada tahun 1838 M di Afghanistan. Ia sangat terbuka dengan ide-ide baru dengan menganjurkan ummat Islam untuk melakukan gerakan intelektual mengikuti pengetahuan modern. Ilmu pengetahuan eropa dianggap sebagai perkembangan dari khazanah pengetahuan warisan Islam. Program yang ia ajukan, ditinjau dari perspektif Islam klasik adalah program intelektual, spiritual dan sekaligus politis (Black,2001:545). Pemikirannya banyak mengupas tentang sistem pemerintahan dalam sebuah negara. Namun demikian ada hal menarik yang dapat diambil yaitu kepemimpinan yang dikehendaki dalam Islam adalah kepemimpinan yang mengedepankan musyawarah dan keadilan yang tentu saja bukan tirani.

Dari beberapa pemikiran para ulama yang telah dijelaskan tersebut di atas, bila dikaji lebih mendalam menunjukkan bahwa persyaratan-persyaratan tersebut sangat ditentukan oleh situasi dan kondisi politik dimana para ulama dan fuqaha berada. Dan juga sejauhmana kedekatan ulama dan penguasa pada saat itu. Sehingga fatwa yang disampaikan sangat diwarnai oleh kondisi politik yang mengitarinya. Misalnya persyaratan fisik yang dikemukakan keempat ulama yaitu al Farabi, al Mawardi, al Ghazali, dan Ibnu Khaldun, tak lepas dari kemajuan dan baiknya mobilitas yang dilakukan pemimpin pada saat itu sebagai cermin dari masyarakat yang maju. Namun, Ibnu Taimiyah yang berpandangan berbeda, bahwa kesehatan jasmani bukan menjadi syarat mutlak dalam kepemimpinan. Syarat ini sangat kontekstual sesuai dengan kondisi negara ataupun sebuah organisasi dan masyarakatnya.

Demikian pula persyaratan tentang orang Qurasy, tidak lepas dari 
keberadaan mereka di Jazirah Arabia khususnya dan Timur Tengah pada umumnya. Sehingga fatwa-fatwa yang mereka sampaikan sangat kontekstual. Namun demikian, sesungguhnya ada kesamaan yang lebih bersifat mayor dari pada minor, yaitu persyaratan yang bersifat fisik, persyaratan yang bersifat mental dan spritual, dan persyaratan yang bersifat keahlian dan kemampuan.

\section{Metode Penelitian}

Dalam rangka menemukan kriteria kepemimpinan Islami, dilakukan dengan studi literatur dari berbagai sumber, terutama kitab dari abad klasik, pertengahan dan modern. Selanjutnya ukuran yang telah ditemukan dianalisis faktor exploratori. Adapun populasi dalam penelitian ini adalah karyawan, dan sampelnya adalah 144 karyawan untuk menilai kepemimpinan dari atasannya langsung. Pimpinan yang dimaksud adalah atasan langsung dari karyawan, baik di fakultas/jurusan maupun bagian administrasi universitas dan unit. Adapun dalam menguji kepemimpinan Islami di UIN Maliki Malang digunakan analisis faktor eksploratori.

\section{Pembahasan}

Setelah mengkaji literatur kitab-kitab klasik, dapat dielaborasi 30 dimensi kepemimpinan Islami. Jika dibandingkan dengan teori kepemimpinan transformasional yang baru berkembang abad 20, ternyata teori tersebut mempunyai item-item yang relevan dengan kepemimpinan Islami. Kepemimpinan transformasional menggunakan pendekatan dari unsur atasan, bawahan dan interaksi keduanya sebagaimana ungkapan Braton. Kepemimpinan Islami mempunyai keunggulan, yaitu menggunakan pendekatan ketuhanan dan moral spiritual, selain tiga unsur dalam kepemimpinan transformasional, yaitu :

a. Pengaruh idealisasi (Idealize influence)

Yaitu suatu sikap yang dekat dengan kharisma yang ditunjukkan dengan sikap, tujuan, tekad dan kepercayaaan pada orang lain. Ini ditunjukkan oleh kriteria para ulama bahwa pemimpin harus mempunyai kewibaan, kejujuran, keadilan, keberanian dan ketegasan.

b. Motivasi inspirasional (Inspirational motivation)

Yaitu perilaku yang menunjukkan motivasi yang memberikan inspirasi kepada bawahan. Seorang pemimpin memiliki kemampuan berbicara secara menarik dan menyenangkan. Ini ditunjukkan oleh kriteria para ulama bahwa pemimpin harus chusnul ibaraoh seperti yang disampikan al Farabi, yaitu baik cara berkomunikasi dengan bawahannya, sehingga mereka termotivasi. Begitu pula al Ghazali dan Ibnu Khaldun yang mengharuskan pemimpin 
dapat mengayomi anak buahnya supaya termotivasi mengembangkan diri. Karena tugas pemimpin adalah menciptakan kebaikan dalam urusan dunia di samping urusan akhirat.

c. Motivasi intelektual (Intelektual motivation)

Yaitu perilaku pemimpin yang memberikan ide-ide baru, inovatif dalam menyelesaikan persoalan. Karena itu pemimpin harus berilmu dan cerdas seperti yang disyaratkan semua ulama.

d. Pertimbangan individu (Individualized consideration)

Yaitu perilaku yang menunjukkan perhatian kepada bawahannya dengan mendengar secara aktif, mengetahui kebutuhan anak buah, serta memberdayakannya. Ini ditunjukkan oleh kriteria para ulama tentang kedekatan dengan rakyat/bawahannya. Kedekatan tersebut dalam rangka mengetahui persoalan yang dihadapi, kemudian dicarikan solusi dan motivasinya, selain itu juga seorang pemimpin harus menjadi tauladan, sehingga masyarakat merasa kagum, percaya, setia, hormat terhadap pemimpinnya.

Selanjutnya 30 item tersebut dianalisis faktor eksploratori, hasilnya menunjukkan bahwa terdapat 25 item yang dapat mengukur kepemimpinan Islami di UIN Maliki Malang, dan ada 5 item yang terbuang, karena nilai loading-nya sangat rendah. Kelima item tersebut adalah item ketulusan, istiqomah menjalankan tugas, ketegasan memberikan sanksi, kedekatan dengan bawahan, dan musyawarah. Adapun dari 25 item terkelompokkan ke dalam 8 faktor/indikator:

1. Kemampuan Manajerial

Faktor/indikator kemampuan manajerial ini merupakan indikator yang paling menonjol dalam mengukur variabel kepemimpinan Islami. Faktor/ indikator ini ditunjukkan dengan 6 item, yaitu : pertama, implementasi renstra yang telah dicanangkan. Penilaian karyawan termasuk kategori cukup baik, dengan skor rata-rata 4.07, karena di setiap fakultas/jurusan/unit di UIN Maliki Malang mempunyai renstra yang menjadi tuntutan dari adanya ISO. Hal ini sesuai dengan prinsip Islam yang menekankan adanya perencanaan, yang kemudian diimplementasikan secara nyata. Nabi SAW, mengajarkan bahwa orang yang melaksanakan perencanaan akan diberi kebaikan 10 dan 700 lipat sampai cabang yang banyak (HR. Muslim: 187, Ahmad 1897). Hadits tersebut mengindikasikan bahwa seorang muslim harus mempunyai rencana dalam beramal, bahkan dalam hadits tersebut digambarkan dengan hitungan matematis. Hal ini dapat diartikan, kerja yang sesuai dengan perencanaan yang telah dibuat akan menghasilkan kinerja yang jauh lebih baik. 
Kedua, penempatan berdasarkan kepasitas karyawan. Penilaian karyawan termasuk kategori cukup baik, dengan skor rata-rata 4.08. Namun masih ada juga karyawan yang merasa ditempatkan tidak sesuai dengan kapasitas dirinya, misalkan tidak memiliki kemampuan bahasa inggris ditempatkan di unit pelayanan yang diharuskan menggunakan bahasa Inggris.

Jika dikaitkan dengan teori kepemimpinan transformasional, item ini termasuk indikator perhatian individu, yaitu mengetahui kemampuan bawahan, sehingga tidak salah dalam menempatkannya, yang hal ini dapat menyebabkan bawahan merasa tidak nyaman dalam bekerja. Akibatnya kinerjanya juga akan rendah. Dalam Islam, keahlian atau kemampuan seseorang harus menjadi pertimbangan dalam pemberian tanggung jawab. Sebagaimana Hadits Nabi, "Apabila sesuatu urusan diserahkan kepada orang yang bukan ahlinya, maka tunggulah saat kehancurannya." (HR. Ahmad 837).

Ketiga, toleran pada semua kelompok. Jika dikaitkan dengan teori transformasional, item ini termasuk pendekatan perhatian pada bawahan, dengan memberikan kesempatan mengembangkan karier dan potensinya. Dan salah satu bentuk implementasi dari keadilan adalah memberikan kesempatan yang sama terhadap bawahan tanpa pandang bulu/latar belakang kelompok dan golongan. Skor rata-rata jawaban responden cukup baik, yaitu 4.04.

Toleran terhadap perbedaan merupakan salah satu misi besar Islam yang mengedepankan persamaan dan keadilan. Sikap adil merupakan suatu sifat yang harus dimiliki oleh seorang pemimpin, dan melaksanakan amanah dan hukum dengan adil merupakan ajaran Allah agar mencapai kemaslahatan dunia dan akhirat (QSan-nisa',4: 135). Al Quran juga mengajarkan bahwa seorang pemimpin harus adil dan tidak mengikuti hawa nafsu (QSal Shad 38: 26). Selain itu, Islam merupakan agama yang rahmatan lil alamin (QSal Anbiya:107), yang harus menjaga kebaikan untuk seluruh ummat manusia. Juga hadits Nabi yang menyatakan "Tidak dikatakan beriman, seseorang yang tidak mencintai saudaranya sesama muslim sebagaimana ia mencintai dirinya sendiri (HR. Bukhari: 12, Muslim: 64-65). Hadits tersebut mengajarkan kecintaan terhadap sesama manusia terutama sesama muslim, agar saling menjaga, melindungi, dan tidak membedakannya karena suatu agama, golongan, suku maupun kelompok tertentu. Ajaran Nabi inilah yang menjadi tanggungjawab seorang pemimpin sebagaimana yang telah diungkapkan oleh al Mawardi, bahwa tugas pemimpin adalah Likhilafati an Nubuwwah fi Hirosati ad Din Wa ssiyasyah ad Dunnya, yakni sebagai pengganti misi kenabian untuk menjaga agama (semua agama), karena kalimat tersebut tidak mengatakan fi khirosati 
al Islam, dan juga mengatur urusan dunia.

Keempat, perhatian terhadap hak bawahan. Rata-rata responden menjawab item ini cukup baik, yaitu 4.10 Ini disebabkan kebanyakan karyawan merasa pimpinan cukup memperhatikan hak-haknya, sekalipun juga sering terjadi keterlambatan dalam pemberian honor. Item ini berkaitan dengan teori kepemimpinan transaksional, yaitu memperhatikan hak material yang harus diterima oleh bawahan, termasuk honor lembur dan honor kepanitiaan. Islam memberikan perhatian besar terhadap pemberian hak bawahan. Nabi bersabda "Berikanlah upah/gaji pekerja sebelum kering keringatnya" (HR.Ibnu Majah:infirad)

Kelima, bertanggungjawab. Dalam teori transformasional, item ini termasuk indikator pengaruh idealisasi, yaitu pimpinan bertanggungjawab atas semua perbuatan atau kebijakan yang dilaksanakan. Sehingga bawahan merasa nyaman dan terlindungi oleh pimpinan. Islam memberikan perhatian yang cukup besar terhadap pekerja dengan memberikan tanggung jawab pada pemimpin yang harus dipertanggungjawabkan di hadapan Allah, sebagaimana yang termaktub dalam hadits Nabi tentang tanggung jawab pemimpin (HR. Muslim: 3408).

Rata-rata responden menjawab item ini cukup baik, yaitu 4.05. Namun, masih juga terjadi pelimpahan tanggung jawab pimpinan kepada karyawan, sehingga karyawan merasa mempunyai tugas yang berat, karena harus melaksanakan tugas pimpinan.

Keenam, memberikan informasi yang diperlukan bawahan. Rata-rata responden menjawab item ini cukup baik, yaitu dengan skor rata-rata 4.07, ini disebabkan kebanyakan karyawan selalu diberikan arahan oleh atasannya. Dalam teori kepemimpinan transformasional, item ini termasuk indikator stimulasi intelektual. Karena pimpinan menekankan prestasi, bukan kegagalan. Dalam Islam, hal tersebut menjadi sifat seorang pemimpin, yaitu sifat tabligh yakni menyampaikan kebenaran dan hal penting yang harus diketahui para karyawannya.

\section{Etos kerja}

Faktor/indikator etos kerja ini merupakan Indikator yang dapat mengukur variabel kepemimpinan Islami. Faktor/indikator tersebut memiliki eigen value sebesar 1.9 dan mampu menjelaskan keragaman (varian) variabel-variabel yang diobservasi sebesar 6.5\%. Faktor/indikator ini ditunjukkan oleh 4 item, yaitu, pertama, kerja keras. Rata-rata responden menilai kerja keras pimpinan cukup 
baik, dengan skor rata-rata 4.42. Nabi menganjurkan umat Islam selalu bekerja keras agar dapat menjadi tangan yang di atas, karena sebagaimana sabdanya, "Tangan di atas lebih baik dari tangan di bawah", termasuk memberikan zakat dan sedekah. Seseorang tidak dapat menjadi posisi muzaki (tangan di atas) jika tidak mempunyai harta yang banyak sebagai hasil dari kerja kerasnya. Kerja keras ini dapat dibudayakan sejak dini. Adapun proses pembudayaan kerja keras dapat dilakukan dengan banyak cara (Shein 2004: 300-301) antara lain dengan pemodelan peran, yakni keteladanan, seorang pemimpin yang bekerja keras akan ditiru oleh bawahannya.

Kedua, kehati-hatian dalam menggunakan aset lembaga. Responden menilai cukup baik terhadap item ini, dengan skor rata-rata 4.33. Menurut beberapa karyawan, kebanyakan pimpinan tidak pernah menggunakan dana lembaga untuk kepentingan pribadi, namun ada beberapa yang menilai pimpinan kurang hati-hati dalam menggunakan aset lembaga. Item ini merupakan salah satu contoh dari larangan tindak korupsi dalam Islam seperti yang disyaratkan al Ghazali pada bab 2. Jika dikaitkan dengan teori kepemimpinan transformasional, item ini termasuk indikator pengaruh idealisasi, yaitu adanya kepercayaan dari bawahan pada pimpinan.

Ketiga, sikap ringan tangan untuk membantu orang lain. Rata-rata responden menjawab item ini cukup baik, yaitu 4.42. Karyawan menilai pimpinan orang yang suka membantu, baik dalam urusan pekerjaan maupun di luar urusan pekerjaan. Misalnya, sekalipun sibuk, pimpinan tetap melayani dan membantu tamu, dosen, ataupun mahasiswa yang datang, dengan tanpa menggerutu ataupun mengeluh. Ketika dikejar deadline, bawahan harus lembur untuk menyelesaikannya, pimpinanpun turut mendukung bahkan juga turut menemani. Namun, ada juga yang dinilai enggan membantu orang lain apalagi bawahan. Hal ini bertentangan dengan ajaran Nabi, bahwa seorang pemimpin merupakan pelayan dari yang dipimpin dengan selalu membantunya.

Keempat, tidak menunda pekerjaan. Jika diaitkan dengan teori perilaku item ini berkaitan dengan orientasi tugas, yaitu menyelesaikan tugas tepat pada waktunya, bahkan selesai sebelum waktunya. Rata-rata responden menjawab item ini cukup baik, yaitu 4.35. Namun menurut beberapa karyawan, terkadang pimpinan menunda pekerjaan karena, lupa tidak memberikan tugas pada bawahan dikarenakan ada tugas lain seperti tugas mengajar bahkan masih studi, sehingga bawahan juga terlambat mengerjakannya. Islam mengajarkan perilaku ketepatan waktu dengan ajaran solat yang harus dilaksanakan pada waktunya (HR.Bukhori: 496). 


\section{Kemulyaan Akhlak}

Indikator kemulyaan akhlak ini dapat mengukur kepemimpinan Islami. Faktor/indikator tersebut memiliki eigen value sebesar 1.5 dan mampu menjelaskan keragaman (varian) variabel-variabel yang diobservasi sebesar $5.1 \%$. Indikator ini meliputi item kejujuran, kesantunan dalam berkata, dan kerendahan hati. Responden menilai item kejujuran cukup baik, begitupun dengan kerendahan hati, namun menilai relatif rendah terhadap item kesantunan. Hal ini disebabkan sebagian pimpinan beranggapan bahwa kesantunan dalam berkata bukanlah sesuatu yang penting agar bawahan tidak mempunyai power distance dengan pimpinan. Oleh sebab itu setiap tugas yang diberikan kepada bawahan bersifat instruksional, tanpa basa-basi, karena sudah menjadi tupoksi dan tanggungjawabnya. Selain itu adanya pengaruh budaya Jawa Timuran yang cenderung terbuka dan keras.

Jika merujuk pada teori perilaku kepemimpinan (Yukl,2001: 65), sebagian pimpinan di UIN Malang mempunyai karakteristik berorientasi tugas, yakni menekankan pelaksanaan tugas semata, dan sebagaian besar pimpinan berorientasi hubungan yakni sangat memperhatikan hubungan dengan bawahan, sehingga kesantunan dan kerendahan hatipun sangat dijaga. Islam mengajarkan bahwa seorang pemimpin harus menjadi teladan atau uswah hasanah bagi yang dipimpin (QS al Ahzab,33: 21) melalui sikap dan perilaku jujur, santun dan rendah hati.

\section{Pengetahuan Agama}

Faktor/indikator pengetahuan agama dapat digunakan untuk mengukur kepemimpinan Islami. Faktor/indikator tersebut memiliki eigen value sebesar 1.3 dan mampu menjelaskan keragaman (varian) variabel-variabel yang diobservasi sebesar $4.3 \%$. Pimpinan di fakultas agama seperti Syari'ah dan Tarbiyah, kualitas bacaan al Qurannya sangat baik, begitu pula dengan pemahamannya. Namun tidak demikian di fakultas umum. Jika merujuk pendapat al Ghazali, bahwa ilmu agama merupakan ilmu fardu ain yang wajib dipelajari oleh setiap mukmin, dan semua ulama mensyaratkan seorang pemimpin harus memahami pengetahuan agama sebagai sumber dalam bertindak dan berperilaku.

\section{Kemampuan Intelektual}

Faktor/indikator ini dapat mengukur kepemimpinan Islami dengan eigen value sebesar 1.2 dan mampu menjelaskan keragaman (varian) variabel- 
variabel yang diobservasi sebesar 4.0\%. Faktor/indikator ini meliputi 4 item, yaitu ide/gagasan baru, keahlian, kemampuan diplomasi, cepat tanggap menyelesaikan masalah. Karyawan menilai cukup baik terhadap item-item tersebut dengan skor rata-rata di atas 4 , namun menilai relatif rendah terhadap item menyelesaikan masalah secara tepat dan bijak. Dalam teori kepemimpinan, item ini termasuk indikator teori pembawaan atau karakter. Seorang pemimpin yang efektif adalah seorang yang mempunyai karakter berpikir cepat dan visioner, sehingga selalu mempunyai gagasan-gagasan baru untuk mengembangkan lembaga. Al Quran menekankan pentingnya ilmu, baik itu ilmu yang fardlu ain maupun yang fardlu kifayah. Dalam tafsir al Misbah (Shihab,2005,vol.4: 362) dijelaskan bahwa Allah menjadikan manusia sebagai khalifah dengan meninggikan derajat akal, ilmu, dan lain-lain. Jadi, ayat tersebut menunjukkan bahwa seorang pemimpin harus mempunyai keunggulan, agar dapat mempengaruhi orang lain.

\section{Perhatian Pada Bawahan}

Indikator ini dapat mengukur kepemimpinan Islami. Faktor/indikator tersebut memiliki eigen value sebesar 1.1 dan mampu menjelaskan keragaman (varian) variabel-variabel yang diobservasi sebesar 3.9\%. indikator ini meliputi 3 item, yaitu kemauan membimbing, penghargaan dan kepedulian terhadap bawahan. Karyawan menilai item tersebut cukup baik dengan skor rata-rata di atas 4, namun menilai relatif rendah terhadap item kemauan membimbing bawahan, baik bimbingan yang terkait dengan pekerjaan maupun bimbingan keagamaan dan lainnya. Menurut beberapa responden, pimpinan kurang mempunyai waktu untuk membimbing, tetapi jika dimintai, pimpinan juga mau meluangkan waktunya. Nabi menganjurkan agar setiap muslim saling menasihati (HR. Muslim: 83-85)

\section{Pemberdayaan}

Indikator ini dapat mengukur kepemimpinan Islami dengan eigen value sebesar 1.05 dan mampu menjelaskan keragaman (varian) variabel-variabel yang diobservasi sebesar 3.5\%. Indikator ini meliputi 1 item, yaitu memberdayakan bawahan dengan meningkatkan kapasitasnya melalui seminar atau lainnya. Karyawan menilai cukup baik, karena pimpinan masih memberikan izin kepada karyawan untuk mengikuti seminar ataupun melanjukan kuliah dengan syarat tugas kantor tidak terganggu. Menurutnya, pimpinan belum memberikan bantuan kepada karyawan yang melanjutkan kuliah. 
Dalam Islam item ini sebagai upaya mengembangkan karyawan. Tidak dikatakan sempurna Islamnya jika seorang pemimpin tidak mengembangkan bawahannya untuk menambah pengetahuan baru. Hadits Nabi "Islam yang sempurna adalah menyelamatkan saudara sesama muslim dengan lisan dan tangannya" (HR. Muslim: 57). Menyelamatkan dapat diartikan menyelamatkan dari ketidaktahuan dan ketertinggalan, baik meningkatkan pengetahuannya maupun keterampilannya.

\section{Pengendalian Emosi.}

Indikator pengendalian emosi dapat mengukur variabel kepemimpinan Islami. Faktor/indikator tersebut memiliki eigen value sebesar 1.01 dan mampu menjelaskan keragaman (varian) variabel-variabel yang diobservasi sebesar 3.3\%, dan dinilai karyawan relatif lebih rendah dari ketujuh indikator lainnya, sehingga masih terjadi pemimpin memarahi bawahan, atau cenderung menampakkan ekspresi kesal, padahal ini sangat tidak dianjurkan dalam Islam. Bahkan Islam mengajarkan bersikap sabar dalam kondisi apapun, dan memerangi hawa nafsu termasuk emosi merupakan jihad yang terbesar. Allah memberikan konsep agar berhati lemah-lembut, karena jika bersikap keras dan kasar maka mereka pasti akan menjauh, jika mereka berbuat kesalahan maka seorang pemimpin hendaknya memaafkannya (QS Ali Imran: 159).

\section{Simpulan}

Hasil studi ini menambah kekayaan ilmu pengetahuan dan kajian teoritik tentang teori kepemimpinan. Jika dibandingkan dengan teori modern tentang kepemimpinan transformasional, maka nampak perbedaan yang mendasar, yaitu kepemimpinan transformasional menggunakan pendekatan dari unsur atasan, bawahan dan interaksi keduanya, sedangkan pendekatan kepemimpinan Islami lebih luas, yaitu menggunakan pendekatan kemanusiaan yang mempunyai karakter keagamaan dan moral spirit, selain tiga unsur dalam kepemimpinan transformasional.

Dalam kaitannya dengan pengembangan studi empiris, hasil studi ini memberikan kontribusi untuk pengembangan lembaga pendidikan Islam kedepan maupun organisasi keagamaan lainnya, guna tercapainya kinerja organisasi yang baik. Implikasi praktik dari studi ini adalah kepemimpinan yang dapat dikembangkan di perguruan tinggi Islam adalah kepemimpinan Islami.

Sebagai saran, pemimpin di UIN Maliki Malang hendaknya lebih 
memperhatikan indikator pengendalian emosi, karena indikator ini dinilai relatif paling rendah oleh responden (karyawan). Untuk penelitian yang akan datang disarankan untuk melaksanakan penelitian dengan menggunakan responden pada karyawan dalam lingkup yang lebih luas, dan dapat diuji pengaruhnya terhadap kinerja karyawan maupun dosen dan juga organisasi.

\section{Daftar Pustaka}

Al Farabi. as Siyasah al Madaniyah. Maktabah Samilah. versi 2.

Al Farabi. 1994. as Siyasah al Madaniyah. Beirut,Dar wa Maktabah al Hilal.

Al Mawardi, Abu al Hasan; Ali bin Muhammad bin Muhammad. al Ahkam as Sulthaniyyah. Maktabah Syamilah. Versi 2.11.

Al Rozi, Abu Abdillah Fahruddin. Tafsir kabir Ar Rozi. juz 8 (maktabah syamilah versi: 2.11).

Antony, Black. 2001. alih bahasa Abdullah Ali dan Mariana. Pemikiran Politik Islam dari Masa Nabi hingga Masa Kini. Jakarta: Serambi Ilmu Semesta.

Antonio, Syafii, Muhammad. 2007. Muhammad Super Leader Super Manajer. Jakarta: Tazkiya Multimedia.

Bakar, Osman. 1997. Hirarkhi Ilmu. Terjemahan oleh Purwanto. Bandung: Mizan.

Fathiyyah Nabrawy dan Muhammad Nasr. 1984. vol. II.Tathawwur a Fikry as Siyasi fi al Islâm. Kairo: Dâr al Ma'ârif.

Ibnu Khaldun. Muqaddimah. al maktabah al syamilah versi 2.09 dan 2.11.

Ibnu Taimiyah. Siyasah al Syar'iyah juz 1. al Maktabah asy Syamilah. versi 2.11 .

Kreitner, Robert, and Kinicki, Angelo, 2005, Perilaku Organisasi, alih Bahasa Erly Suwandi, Jakarta, Salemba Empat.

Mukti, Muhammad, Ali Abdul. 2010. Filsafat Politik antara barat dan Islam. Terjemahan oleh Rosihaon Anwar. Bandung: Pustaka Setia.

Robbins, Stephen P. 2008. Perilaku Organisasi. Terjemahan oleh Diana Angelika,dkk. Jakarta: Salemba Empat.

Shihab, Quraisy. 2005. Tafsir al Misbah. Jakarta: Lentera Hati. 